Article

\title{
Synthesis of $\mathrm{Al}_{2} \mathrm{Ca}$ Dispersoids by Powder Metallurgy Using a Mg-Al Alloy and $\mathrm{CaO}$ Particles
}

\author{
Junji Fujita ${ }^{1,2, *}$, Junko Umeda ${ }^{3}$ and Katsuyoshi Kondoh ${ }^{3}$ \\ 1 HI-LEX CORPORATION, 1-12-28 Sakaemachi, Takarazuka-City, Hyogo 665-0845, Japan \\ 2 Graduate School of Engineering, Osaka University, 2-1 Yamadaoka, Suita, Osaka 565-0871, Japan \\ 3 Joining and Welding Research Institute, Osaka University, 11-1 Mihogaoka, Ibaragi, Osaka 567-0047, Japan; \\ umedaj@jwri.osaka-u.ac.jp (J.U.); kondoh@jwri.osaka-u.ac.jp (K.K.) \\ * Correspondence: jun-fujita@hi-lex.co.jp; Tel.: +81-797-852-571
}

Received: 1 June 2017; Accepted: 22 June 2017; Published: 28 June 2017

\begin{abstract}
The elemental mixture of Mg-6 wt \%Al-1 wt \%Zn-0.3 wt \%Mn (AZ61B) alloy powder and $\mathrm{CaO}$ particles was consolidated by an equal-channel angular bulk mechanical alloying (ECABMA) process to form a composite precursor. Subsequently, the precursor was subjected to a heat treatment to synthesize fine $\mathrm{Al}_{2} \mathrm{Ca}$ particles via a solid-state reaction between the $\mathrm{Mg}-\mathrm{Al}$ matrix and $\mathrm{CaO}$ additives. Scanning electron microscopy-energy-dispersive spectroscopy (SEM-EDS) and electron probe micro-analysis on the precursor indicated that $4.7-$ at $\% \mathrm{Al}$ atoms formed a supersaturated solid solution in the $\alpha-\mathrm{Mg}$ matrix. Transmission electron microscopy-EDS and X-ray diffraction analyses on the AZ61B composite precursor with 10-vol \% CaO particles obtained by heat treatment confirmed that $\mathrm{CaO}$ additives were thermally decomposed in the $\mathrm{Mg}-\mathrm{Al}$ alloy, and the solid-soluted $\mathrm{Ca}$ atoms diffused along the $\alpha-\mathrm{Mg}$ grain boundaries. $\mathrm{Al}$ atoms also diffused to the grain boundaries because of attraction to the $\mathrm{Ca}$ atoms resulting from a strong reactivity between $\mathrm{Al}$ and $\mathrm{Ca}$. As a result, needle-like $(\mathrm{Mg}, \mathrm{Al})_{2} \mathrm{Ca}$ intermetallics were formed as intermediate precipitates in the initial reaction stage during the heat treatment. Finally, the precipitates were transformed into spherical $\mathrm{Al}_{2} \mathrm{Ca}$ particles by the substitution of $\mathrm{Al}$ atoms for $\mathrm{Mg}$ atoms in $(\mathrm{Mg}, \mathrm{Al})_{2} \mathrm{Ca}$ after a long heat treatment.
\end{abstract}

Keywords: magnesium alloys; powder metallurgy; composite materials; microstructure; phase transformation; transmission electron microscopy

\section{Introduction}

Magnesium alloys are remarkably lightweight due to the low density of $\mathrm{Mg}\left(\sim 1.74 \mathrm{~g} / \mathrm{cm}^{3}\right)$. Their application to structural components in automobiles can improve fuel consumption [1-4]. In particular, the weight reduction of engine blocks and transmission cases used at elevated temperatures $\left(120-200{ }^{\circ} \mathrm{C}\right)$ is very important [4-6]. However, the tensile strength of $\mathrm{Mg}$ alloys drastically decreases at elevated temperatures. This prevents their widespread use in the automotive industry [5-7]. Therefore, it is necessary to improve the heat resistance of $\mathrm{Mg}$ alloys. Previous studies have reported that the addition of calcium to $\mathrm{Mg}-\mathrm{Al}$ alloys improved the creep resistance at $200{ }^{\circ} \mathrm{C}$ by the formation of $\mathrm{Al}_{2} \mathrm{Ca}$ or $(\mathrm{Mg}, \mathrm{Al})_{2} \mathrm{Ca}$ intermetallic compounds around the $\alpha-\mathrm{Mg}$ grain boundaries [8-10]. This is because these network-structured compounds prevented both the deformation of $\alpha-\mathrm{Mg}$ grains and grain boundary sliding at elevated temperatures. On the other hand, these network-structured compounds potentially cause grain boundary fractures. Fine dispersed particles of intermetallic compounds are more effective to improve the yield stress of $\mathrm{Mg}$ alloys via pinning effects.

In the present study, $\mathrm{CaO}$ particles are employed as raw materials to disperse fine $\mathrm{Al}_{2} \mathrm{Ca}$ particles in an $\alpha-\mathrm{Mg}$ matrix via a solid-state reaction between $\mathrm{CaO}$ particles and the $\mathrm{Mg}-\mathrm{Al}$ alloy. The conventional $\mathrm{Mg}-\mathrm{Al}$ alloys reinforced with fine $\mathrm{Al}_{2} \mathrm{Ca}$ particles are expected to demonstrate both 
excellent yield stress by pinning effects and high cost performance because of the use of inexpensive $\mathrm{CaO}$ particles as raw materials. However, from a thermodynamic point of view, an Ellingham diagram of the oxide formation [11] indicates that $\mathrm{CaO}$ reduction by $\mathrm{Mg}$ never occurs in the solid state (up to $650^{\circ} \mathrm{C}$ ). Therefore, the $\mathrm{CaO}$ raw particles should remain in the cast $\mathrm{Mg}$ material. In contrast, our previous study [12] reported that $\mathrm{CaO}$ reduction with $\mathrm{Al}_{2} \mathrm{Ca}$ and $\mathrm{MgO}$ formation occurred in the Mg-6 wt \%Al-1 wt \%Zn-0.3 wt \%Mn (AZ61B) alloy instead of pure Mg because the change in the standard free energy became negative. As a result, $\mathrm{Al}_{2} \mathrm{Ca}$ phases were synthesized in the $\mathrm{AZ61B}$ alloy. Furthermore, $\mathrm{CaO}$ particles homogeneously dispersed in the $\alpha-\mathrm{Mg}$ matrix contributed to forming the $\mathrm{Al}_{2} \mathrm{Ca}$ fine particles via a solid-state synthesis. Another study [13] reported that $\mathrm{Mg}-6 \mathrm{wt} \% \mathrm{Al}$ alloy (AM60) powder composites with $\mathrm{CaO}$ additive particles demonstrated a higher creep resistance at $175^{\circ} \mathrm{C}$ than those of the ADC12 aluminum alloy. This is because these composites were reinforced with $\mathrm{Al}_{2} \mathrm{Ca}$ fine dispersoids formed via a solid-state reaction between the $\mathrm{CaO}$ particles and the AM60 alloy.

Nevertheless, the reaction mechanism for $\mathrm{CaO}$ reduction in $\mathrm{Mg}-\mathrm{Al}$ alloys is not yet clear. For example, a previous study [12] revealed that needle-like intermetallics were formed as intermediate precipitates from the solid-state reaction, as shown in Figure 1. However, the crystal structure was not completely identified. Furthermore, the reaction process of the $\mathrm{Al}_{2} \mathrm{Ca}$ synthesis was also not clear. The same study [12] suggests that the progress of this reaction is governed by the diffusion behavior of $\mathrm{Al}$ atoms to $\mathrm{CaO}$ particles. This is because $\mathrm{Al}_{2} \mathrm{Ca}$ formation was more clearly detected after heat treatment at higher temperatures as shown in Figure 2 [12]. By contrast, Figure 2 also reveals that the progress of the $\mathrm{Al}_{2} \mathrm{Ca}$ synthesis was promoted by the increase of $\mathrm{CaO}$ additive particles. In particular, no $\mathrm{Al}_{2} \mathrm{Ca}$ was detected in the $\mathrm{Mg}-\mathrm{Al}-\mathrm{CaO}$ precursor with 2.5-vol \% CaO particles. This reason cannot be well-explained by only the diffusion behavior of $\mathrm{Al}$ atoms because all of the $\mathrm{CaO}$ particles should contact the $\mathrm{Al}$ atoms solid-soluted in the $\alpha-\mathrm{Mg}$ matrix during the heat treatment.

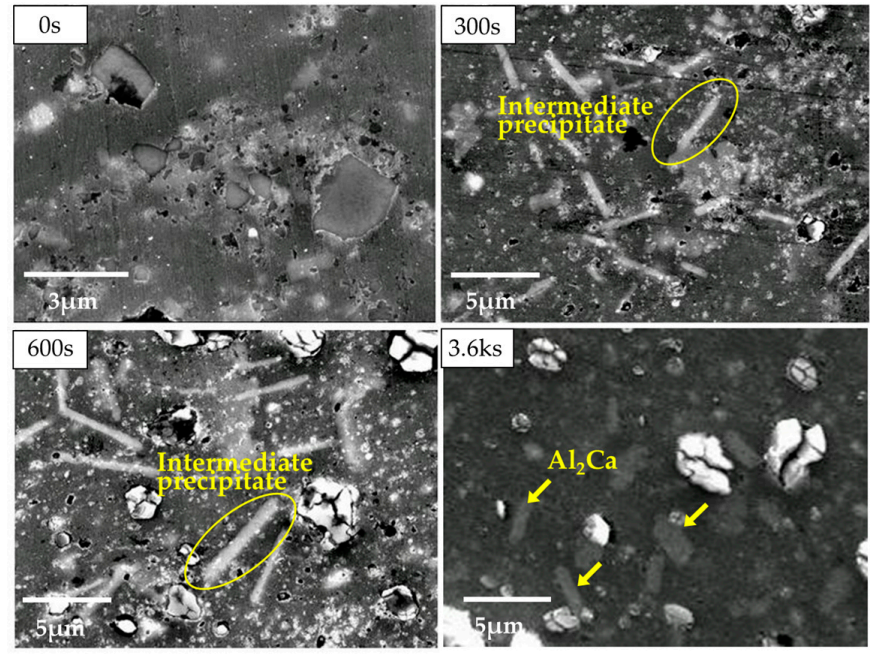

Figure 1. Scanning electron microscopy (SEM) observation on the Mg-Al-CaO precursors with $10-\mathrm{vol} \%$ $\mathrm{CaO}$ particles after the heat treatment at $500{ }^{\circ} \mathrm{C}$ for $0 \mathrm{~s}, 300 \mathrm{~s}, 600 \mathrm{~s}$ and $3.6 \mathrm{ks}$.

In this study, the synthesis mechanism of $\mathrm{Al}_{2} \mathrm{Ca}$ intermetallic compounds via a reaction of $\mathrm{CaO}$ additives dispersed in an AZ61B composite precursor during heat treatment was investigated in detail by scanning electron microscopy (SEM), transmission electron microscopy (TEM), electron probe micro-analysis (EPMA), and X-ray diffraction (XRD) analysis. The atomic distribution of $\mathrm{Mg}, \mathrm{Al}$, and Ca was determined by TEM-energy-dispersive spectrometry (EDS) and XRD analysis using the AZ61B composite precursor with $10-\mathrm{vol} \% \mathrm{CaO}$ particles at the initial stage of the heat treatment. The synthesis of $(\mathrm{Mg}, \mathrm{Al})_{2} \mathrm{Ca}$ intermediate precipitates was also detected through crystal structure analysis by XRD and TEM-EDS analysis. 


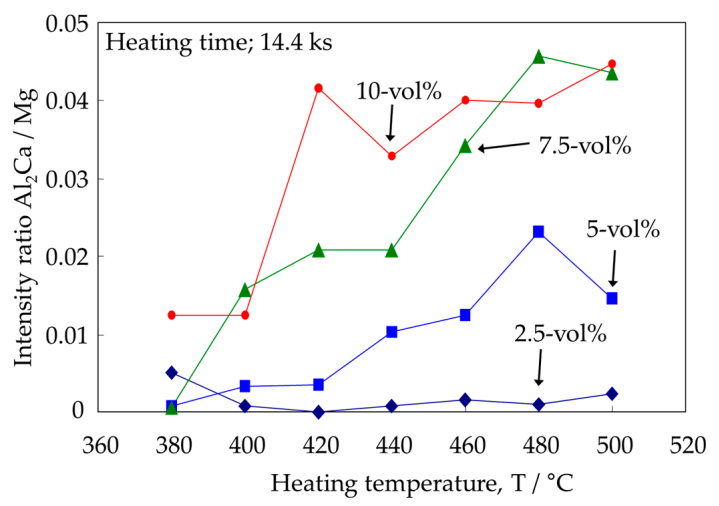

Figure 2. Dependence of $\mathrm{X}$-ray diffraction $(\mathrm{XRD})$ peak intensity ratio of $\mathrm{Al}_{2} \mathrm{Ca}$ and $\mathrm{Mg}$ peaks on heating temperature of $\mathrm{AZ} 61 \mathrm{~B}$ powder precursors with various contents of $\mathrm{CaO}$ particles.

\section{Materials and Methods}

\subsection{Preparation of AZ61B Precursors Containing CaO Particles}

AZ61B chips machined from their original cast ingot (Al; 6.41, Zn; $1.02, \mathrm{Mn} ; 0.28, \mathrm{Si} ; 0.02, \mathrm{Fe} ; 0.004$, $\mathrm{Cu} ; 0.002, \mathrm{Ni} ; 0.0007, \mathrm{Mg}$; Bal./mass \%) were employed as raw materials. They had a mean particle size of $1.38 \mathrm{~mm}$ as measured by a particle size analyzer (LA-950, HORIBA, Kyoto, Japan). CaO particles for use as additives, having a mean particle size of $2.3 \mu \mathrm{m}$, were prepared from CaO blocks with a purity of $98 \%$ or more via mechanical fragmentation using a ball milling process. The elemental mixtures of the AZ61B chips and $\mathrm{CaO}$ particles were mixed by rocking mill equipment (RM-05S, Seiwa Giken Co., Hiroshima, Japan) and used as the starting materials. The content of the $\mathrm{CaO}$ additives was $10-\mathrm{vol} \%$. It is effective to disperse $\mathrm{CaO}$ additive particles homogeneously in the $\mathrm{Mg}-\mathrm{Al}$ alloy matrix in order to form $\mathrm{Al}_{2} \mathrm{Ca}$ fine particles via a solid-state synthesis during the heat treatment. Therefore, a severe plastic working was applied to the AZ61B green compacts containing $\mathrm{CaO}$ particles by an equal-channel angular bulk mechanical alloying (ECABMA) process [14], where cold compaction and extrusion within a channel bent were alternately carried out in the die, as illustrated in Figure 3. The maximum compaction pressure was $611 \mathrm{MPa}$. The ECABMA process was repeated 50 times in total resulting in the homogeneous dispersion of the $\mathrm{CaO}$ additive particles in the AZ61B alloy chip matrix. This process was also effective for the mechanical breakage of the $\mathrm{MgO}$ surface oxide films of the AZ61B chips, and resulted in the formation of newly created $\mathrm{Mg}$ active surfaces of the chips that directly came into contact with the $\mathrm{CaO}$ particles. The green compact billet ( $\mathrm{Mg}-\mathrm{Al}-\mathrm{CaO}$ precursor) prepared by the above process had a $35 \mathrm{~mm}$ diameter and an $80 \mathrm{~mm}$ length.

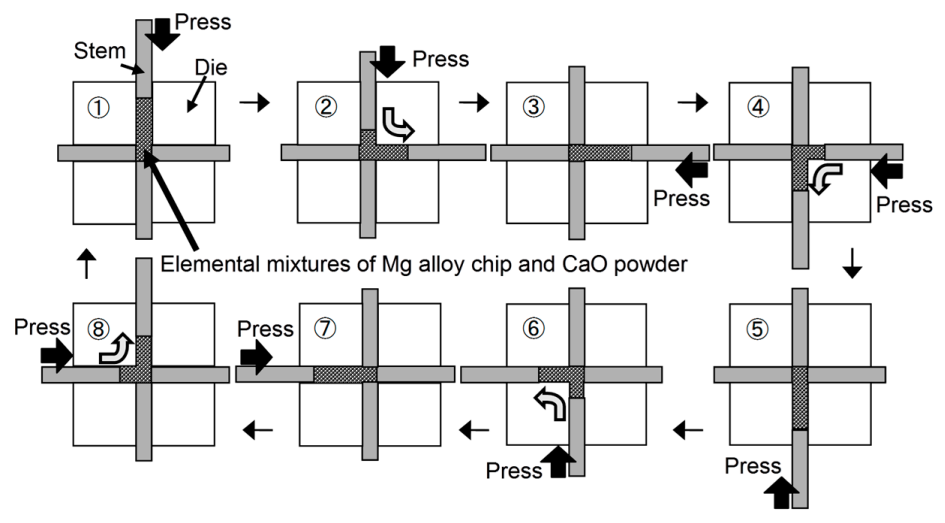

Figure 3. Schematic illustration of one cycle of equal channel angular bulk mechanical alloying (ECABMA) process used in fabrication of $\mathrm{Mg}$ alloy powder precursor containing $\mathrm{CaO}$ particles. 


\subsection{Heat Treatment of AZ61B Composite Precursor with CaO Particles}

A heat treatment at $500{ }^{\circ} \mathrm{C}$ in an argon gas atmosphere was applied to the precursor in order to investigate the reaction behavior between the $\mathrm{AZ} 61 \mathrm{~B}$ matrix and the $\mathrm{CaO}$ particles in the initial stage. The heating time at $500{ }^{\circ} \mathrm{C}$ was $300 \mathrm{~s}$. For the investigation of the $\mathrm{Al}$ atom distribution in the AZ61B matrix, the aging heat treatment of the AZ61B precursor with no $\mathrm{CaO}$ particle was conducted at $200{ }^{\circ} \mathrm{C}$ for $86.4 \mathrm{ks}$ in vacuum.

\subsection{Microstructural Analysis}

A field emission scanning electron microscope (JSM-6500F, JEOL, Tokyo, Japan) equipped with an energy-dispersive X-ray spectrometer (EX-64175 JMU, JEOL) was used to investigate the microstructures of the AZ61B powder precursor with no $\mathrm{CaO}$ particle. The chemical composition of the $\mathrm{Mg}-\mathrm{Al}$ matrix was investigated by an electron probe micro-analyzer (EPMA, JXA-8530F, JEOL). The number of the EPMA measurement point was 15, and the mean value was calculated. A transmission electron microscope (JEM-2100F, JEOL) equipped with an energy dispersive X-ray spectrometer (EX-37001, JEOL) was used to investigate the microstructures of the heat treated precursors. X-ray diffraction analysis (XRD-6100, Shimadzu, Kyoto, Japan) was used to clarify the crystal structure of the $\alpha-\mathrm{Mg}$ matrix and identify the intermediate precipitates.

\section{Results and Discussion}

\subsection{Microstructural and Compositional Analysis on the AZ61B Matrix with No CaO Particle}

The microstructures and compositions of the AZ61B powder precursor with no $\mathrm{CaO}$ particles were investigated. As shown in Figure 4, SEM on the AZ61B powder precursor after the ECABMA process suggests that coarse $\beta$-phases $\left(\mathrm{Mg}_{17} \mathrm{Al}_{12}\right)$, having a particle size of $2-10 \mu \mathrm{m}$, and $\mathrm{Al}_{6} \mathrm{Mn}$ phases were observed in the $\alpha-\mathrm{Mg}$ matrix. Table 1 shows the EPMA analysis results for the $\alpha-\mathrm{Mg}$ matrix in the precursor. The mean value of the $\mathrm{Al}$ composition in the $\alpha-\mathrm{Mg}$ matrix was $4.7-\mathrm{at} \%$ (5.17-wt \%). This means that $80.7 \%$ of the entire $\mathrm{Al}$ content (6.41-wt \%) from the original AZ61B chips was solid-soluted in the $\alpha$-Mg matrix. The remaining $19.3 \%$ contributed to the formation of $\beta$-phases and/or $\mathrm{Al}_{6} \mathrm{Mn}$ compounds. The $\mathrm{Mg}-\mathrm{Al}$ binary phase diagram [15] suggests that a solid solubility limit of $\mathrm{Al}$ into the $\alpha-\mathrm{Mg}$ phase is 1 -at $\%$ or lower below $100{ }^{\circ} \mathrm{C}$. Therefore, the above 4.7 -at $\% \mathrm{Al}$ elements existed as a supersaturated solid-solution state in the matrix of the AZ61B precursor. Figure 5 shows the SEM-EDS analysis results of the precursor after the aging heat treatment at $200{ }^{\circ} \mathrm{C}$ for $86.4 \mathrm{ks}$ in vacuum. Fine $\beta$-phases of less than $\sim 1 \mu \mathrm{m}$ homogeneously existed as dispersoids in the $\alpha$-Mg matrix as well as the coarse $\beta$-phases. This means that the $\alpha$-Mg matrix of the precursor contained an excess of $\mathrm{Al}$ atoms. Fewer $\mathrm{Al}$ atoms could be solid-soluted in the $\alpha$-Mg phase with a thermal stability below $200^{\circ} \mathrm{C}$.

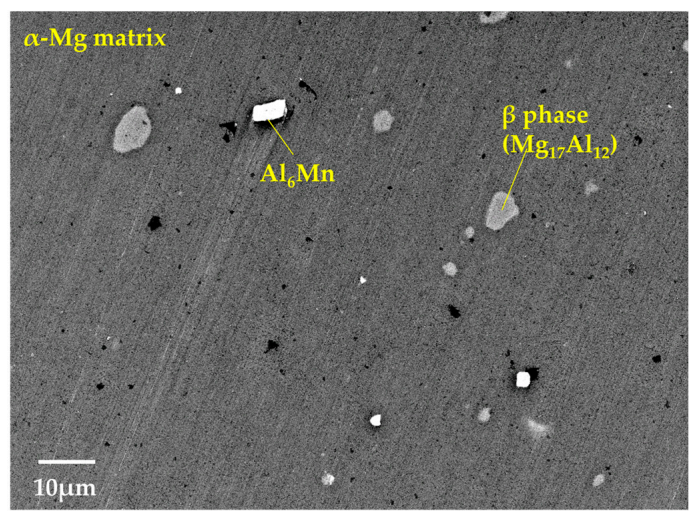

Figure 4. SEM observation on AZ61B powder precursor with no $\mathrm{CaO}$ particle after ECABMA process. 
Table 1. Chemical compositions of the $\alpha$-Mg matrix in AZ61B powder precursor with no CaO particle.

\begin{tabular}{ccccccc}
\hline Element (at \%) & Al & O & Zn & Mn & Mg & Total \\
\hline$\alpha$-Mg matrix & 4.70 & 0.27 & 0.26 & 0.03 & 94.74 & 100.00 \\
\hline
\end{tabular}

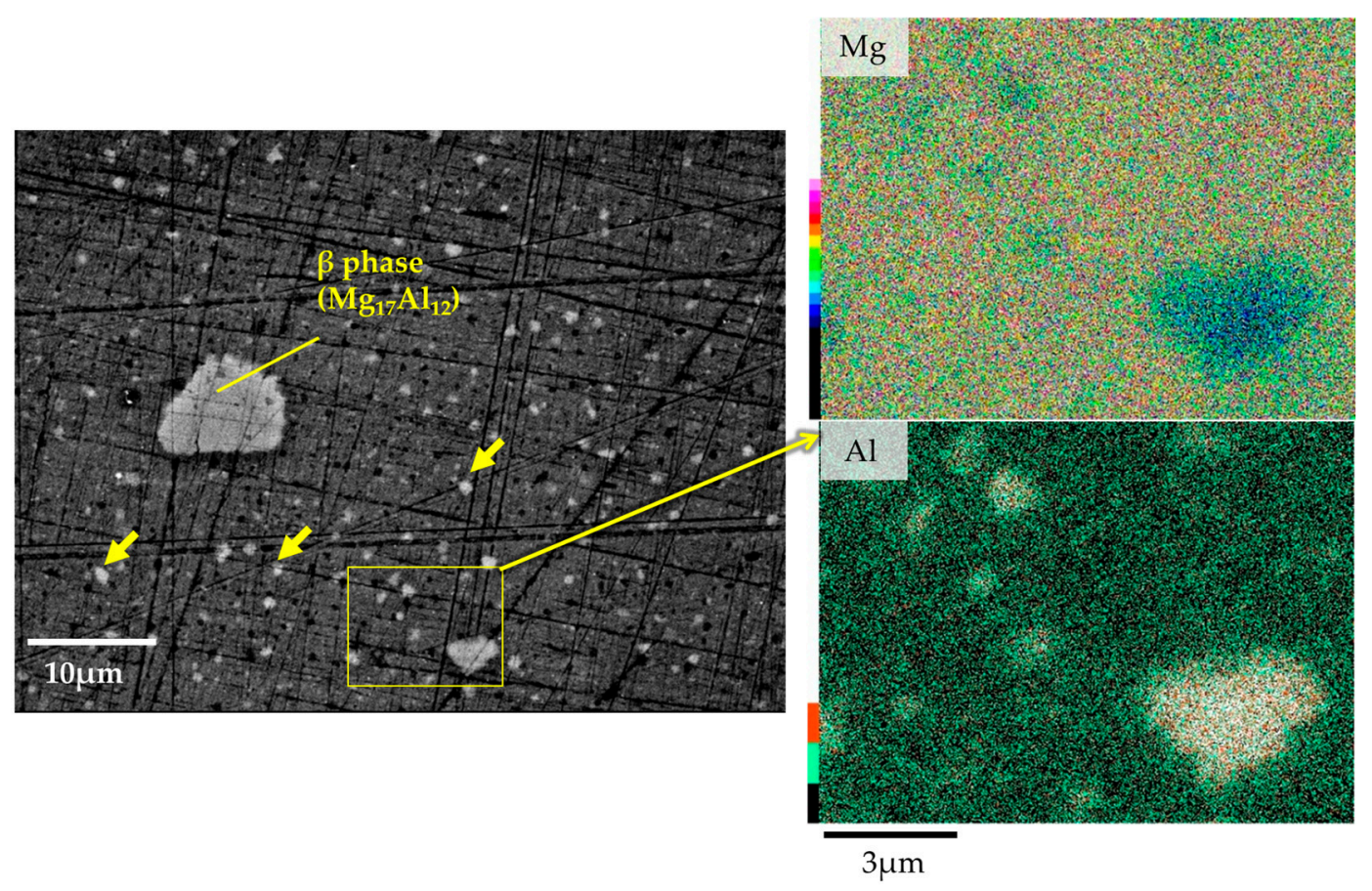

Figure 5. SEM-EDS analysis results of AZ61B powder precursor with no $\mathrm{CaO}$ particle after aging heat treatment at $200{ }^{\circ} \mathrm{C}$ for $86.4 \mathrm{ks}$ in vacuum.

\subsection{Microstructural Analysis on the $\alpha-M g$ Phase of $M g-A l-C a O$ Precursors}

Microstructural changes of the AZ61B composite precursor with 10-vol \% CaO particles at the initial reaction stage were investigated by applying a heat treatment at $500^{\circ} \mathrm{C}$ for $300 \mathrm{~s}$. As shown in Figure 6a, the original $\mathrm{CaO}$ particles and in situ-formed intermediate precipitates observed using scanning transmission electron microscopy (STEM) were dispersed in the $\alpha$-Mg polycrystalline matrix. Figure $6 \mathrm{~b}$ shows a superposition of the TEM observation with an EDS mapping analysis on the $\alpha$-Mg phase in the same sample at area A. The distributions of the $\mathrm{Ca}$ and $\mathrm{Al}$ elements were almost the same. Most elements were detected along the $\alpha-\mathrm{Mg}$ grain boundaries. Figure $6 \mathrm{c}$ shows an electron diffraction pattern for the $\alpha-\mathrm{Mg}$ phase at area B. Numerous $\mathrm{MgO}$ spots were detected. This is because the AZ61B chips had the original natural oxide surface films, and the additional oxidation of the AZ61B powder precursor occurred during the ECABMA process. Except for $\mathrm{MgO}$ and the $\alpha$-Mg matrix, no other compound was detected. According to these results, it was concluded that $\mathrm{Al}$ and $\mathrm{Ca}$ atoms in Figure $6 \mathrm{~b}$ were solid-soluted in the $\alpha-\mathrm{Mg}$ matrix with no formation of Al-Ca compounds. 


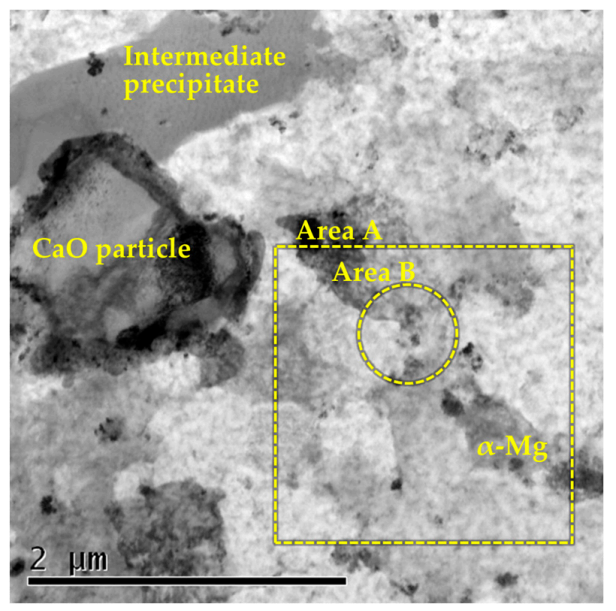

(a) STEM observation.

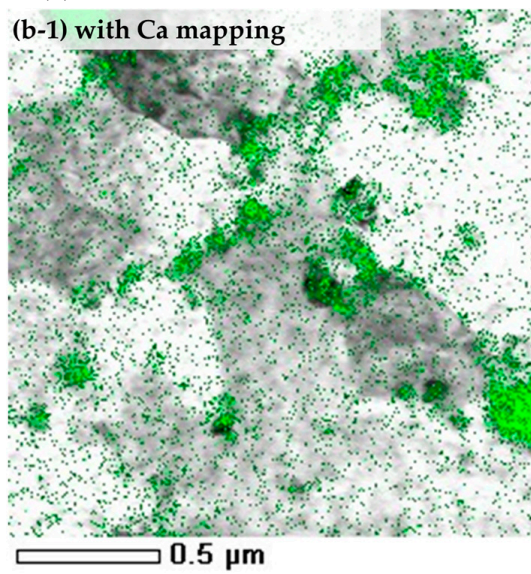

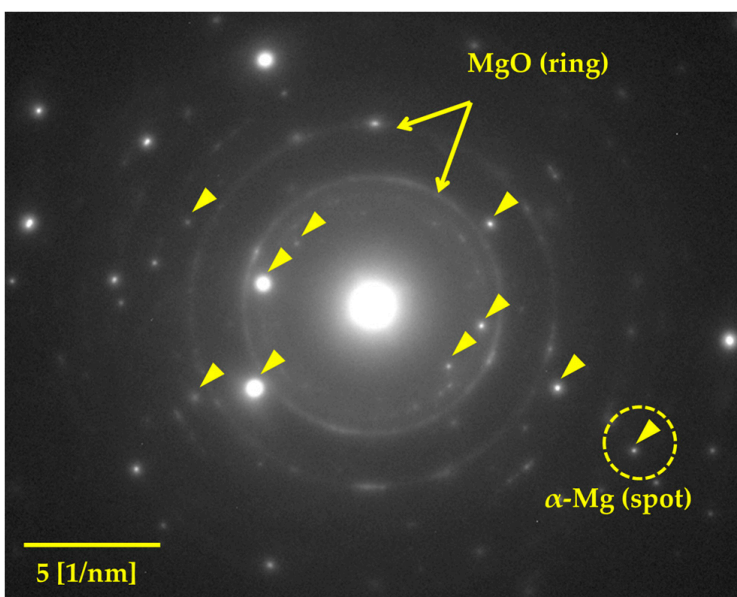

(c) TEM diffraction pattern of the area B in (a). (b-2) with Al mapping 35

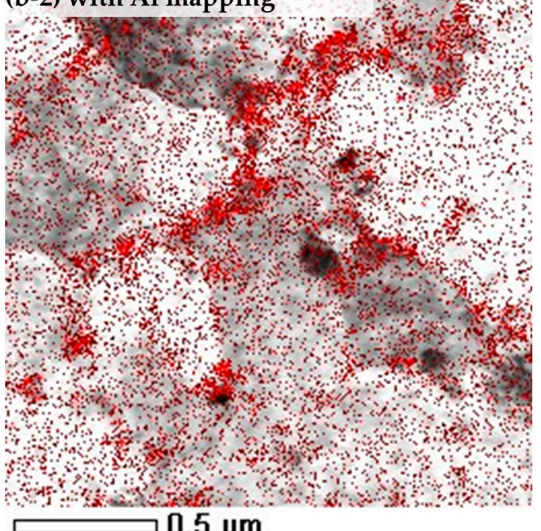

(b) Superposition of TEM observation on the area A in (a) with EDS mapping analysis; $\mathrm{Ca}(\mathbf{b}-\mathbf{1})$ and $\mathrm{Al}(\mathbf{b}-\mathbf{2})$.

Figure 6. Transmission electron microscopy (TEM) observation result of the $\mathrm{Mg}-\mathrm{Al}-\mathrm{CaO}$ precursor with $10-\mathrm{vol} \% \mathrm{CaO}$ particles after the heat treatment at $500{ }^{\circ} \mathrm{C}$ for $300 \mathrm{~s}$. STEM: scanning transmission electron microscopy; EDS: energy-dispersive spectroscopy.

XRD analysis on the same precursor in the as-processed state (before heat treatment) and after the heat treatment at $500{ }^{\circ} \mathrm{C}$ for $300 \mathrm{~s}$ was carried out in order to investigate the crystal structure of $\alpha-\mathrm{Mg}$ by solid solution. As shown in Figure 7, the XRD peak of the $\alpha-\mathrm{Mg}$ phase in the as-processed state shifted to a higher angle compared to the original peak illustrated by the dotted line $\left(2 \theta=47.83^{\circ}\right)$. This shift occurs because most of the Al atoms existed as a supersaturated solid-solution state in the $\alpha-\mathrm{Mg}$ matrix of the as-processed precursor before heat treatment as mentioned in the previous section. Solid-soluted $\mathrm{Al}$ atoms created a smaller lattice spacing in $\alpha-\mathrm{Mg}$ because the atomic radius of $\mathrm{Al}(1.43 \AA)$ is smaller than that of $\mathrm{Mg}(1.60 \AA)$ [16]. On the other hand, the same peak after the heat treatment at $500{ }^{\circ} \mathrm{C}$ for $300 \mathrm{~s}$ shifted to a lower angle. This is because the solid-soluted Al atoms in the $\alpha$-Mg matrix decreased by forming intermediate precipitates containing $\mathrm{Al}$ and $\mathrm{Ca}$ as shown in Figure 6a and the previous study [12]. In addition, the XRD peak shifted to an even lower angle than the original $\alpha-\mathrm{Mg}$ peak, as shown by the dotted line. This means that $\mathrm{Ca}$ atoms were also solid-soluted in the $\alpha-\mathrm{Mg}$ matrix. The lattice spacing became larger than that of the original $\alpha-\mathrm{Mg}$ because of the larger atomic radius of $\mathrm{Ca}(1.97 \AA)$ compared to $\mathrm{Mg}(1.60 \AA)$. Figure 8 shows an isothermal section of the $\mathrm{Mg}-\mathrm{Al}-\mathrm{Ca}$ ternary system in the $\mathrm{Mg}$-rich corner at $450{ }^{\circ} \mathrm{C}$ [17]. It suggests that only a few of the $\mathrm{Ca}$ atoms are soluted in the $\alpha-\mathrm{Mg}$ matrix, where the $\mathrm{Al}$ content is 4.7 -at \% as shown in Table 1. As a result, $\mathrm{Ca}$ atoms can be solid-soluted with thermal stability without Al-Ca precipitate formation when the Ca composition in the $\alpha-\mathrm{Mg}$ matrix is within the solid solubility limit. 


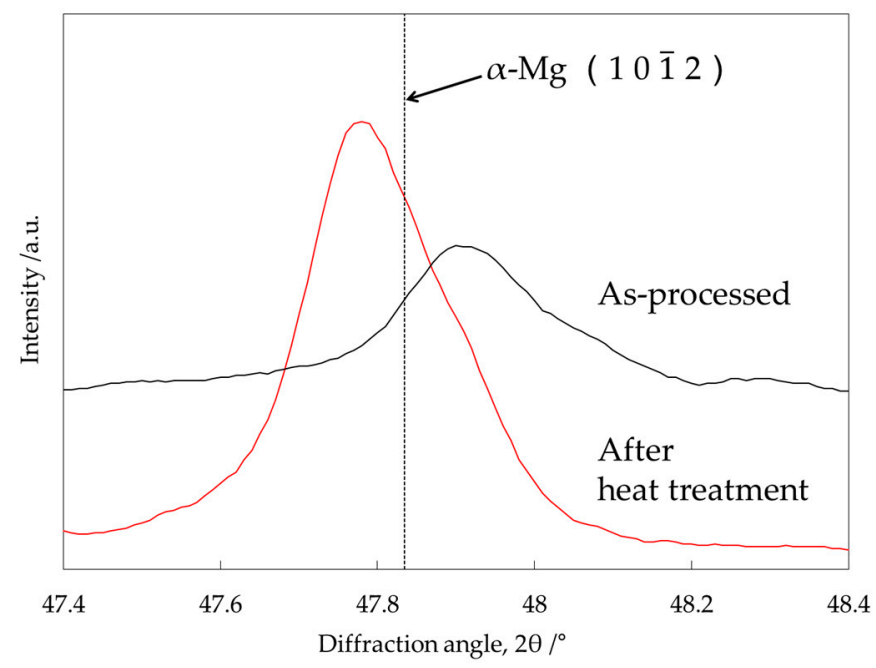

Figure 7. XRD patterns of the $\mathrm{Mg}-\mathrm{Al}-\mathrm{CaO}$ precursors with 10 -vol $\% \mathrm{CaO}$ particles in the as-processed state and after the heat treatment at $500{ }^{\circ} \mathrm{C}$ for $300 \mathrm{~s}$.

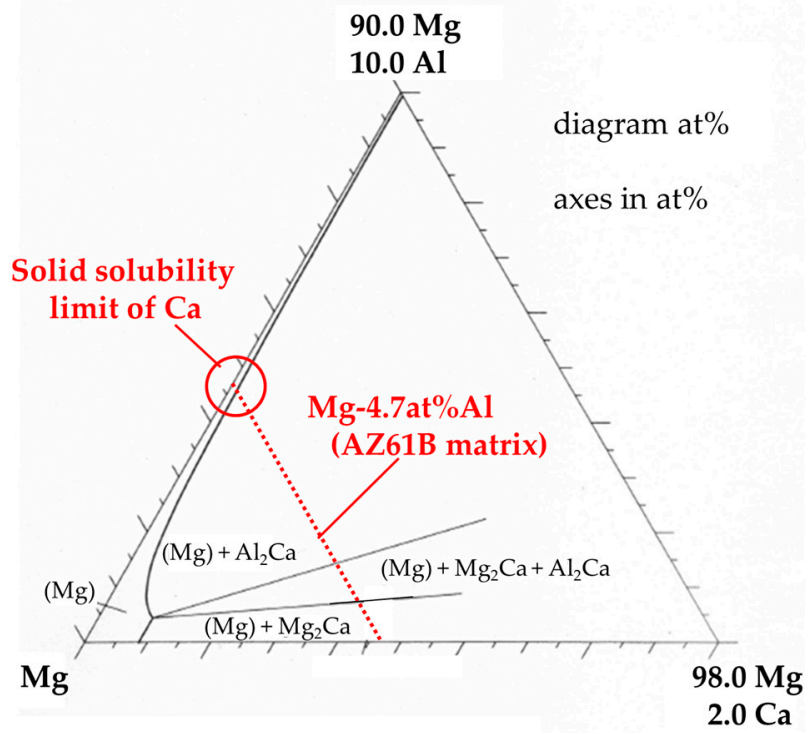

Figure 8. Isothermal section of the Mg-Al-Ca ternary system in Mg-rich corner at $450{ }^{\circ} \mathrm{C}$.

According to the above consideration, when the heat treatment at $500{ }^{\circ} \mathrm{C}$ was applied to the $\mathrm{Mg}-\mathrm{Al}-\mathrm{CaO}$ precursor, $\mathrm{CaO}$ particles were thermally decomposed and $\mathrm{Ca}$ atoms were solid-soluted in the $\alpha-\mathrm{Mg}$ matrix. Then, $\mathrm{Ca}$ atoms diffused along $\alpha-\mathrm{Mg}$ grain boundaries as shown in Figure 6(b-1). $\mathrm{Al}$ atoms originally solid-soluted in the $\alpha-\mathrm{Mg}$ matrix also diffused to the grain boundaries as displayed in Figure 6(b-2). This is because $\mathrm{Al}$ atoms were attracted to the $\mathrm{Ca}$ atoms due to a strong combination of $\mathrm{Al}$ and $\mathrm{Ca}$ elements [18]. As a result, the needle-like intermediate precipitates containing $\mathrm{Al}$ and $\mathrm{Ca}$ atoms were formed along the grain boundaries as shown in Figure 1.

Figure 9 shows TEM-EDS mapping analysis around a $\mathrm{CaO}$ particle of the precursor after the heat treatment at $500{ }^{\circ} \mathrm{C}$ for $300 \mathrm{~s}$. $\mathrm{MgO}$ thin layers were observed around the $\mathrm{CaO}$ particle. They were formed by the solid-state reaction between oxygen atoms originated from $\mathrm{CaO}$ and $\mathrm{Mg}$ atoms in the $\alpha-\mathrm{Mg}$ matrix. This suggests that both $\mathrm{CaO}$ reduction and $\mathrm{Mg}$ oxidation occurred at the interfacial 
surface between $\mathrm{CaO}$ particles and the $\alpha-\mathrm{Mg}$ matrix. In conclusion, the following reaction occurred in the precursor:

$$
\mathrm{Mg}-\mathrm{Al} \text { solid solution }+\mathrm{CaO} \rightarrow \mathrm{Mg}-\mathrm{Al}-\mathrm{Ca} \text { solid solution }+\mathrm{MgO} \text {. }
$$

Based on the above consideration, it is expected that $\mathrm{CaO}$ reduction could occur in the $\mathrm{Mg}-\mathrm{Al}$ alloy regardless of $\mathrm{CaO}$ content. However, our previous study [12] reported that no formation of an $\mathrm{Al}_{2} \mathrm{Ca}$ phase was detected in a $\mathrm{Mg}-\mathrm{Al}-\mathrm{CaO}$ precursor with $2.5-\mathrm{vol} \% \mathrm{CaO}$ particles as shown in Figure 2. This is possibly because a lower $\mathrm{CaO}$ content caused a smaller amount of $\mathrm{Ca}$ atoms to be solid-soluted in the matrix. This reaction behavior must be investigated in detail for situations of low $\mathrm{CaO}$ content.
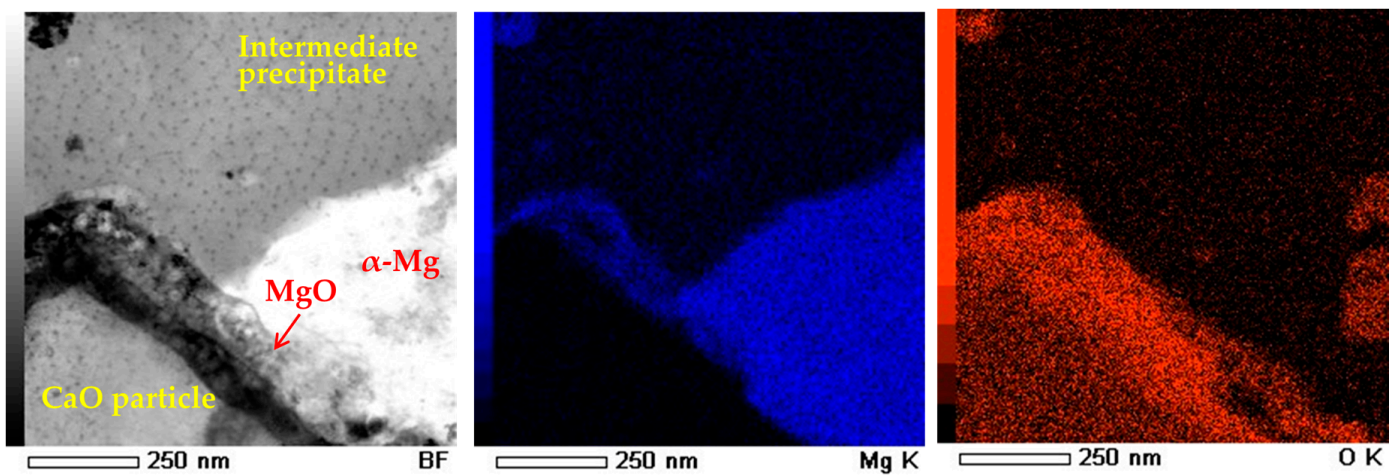

Figure 9. TEM-energy-dispersive spectroscopy (TEM-EDS) mapping analysis around CaO particle in the $\mathrm{Mg}-\mathrm{Al}-\mathrm{CaO}$ precursor with $10-\mathrm{vol} \% \mathrm{CaO}$ particles after the heat treatment at $500{ }^{\circ} \mathrm{C}$ for $300 \mathrm{~s}$.

\subsection{Mirostructural Analysis of the Intermediate Precipitates by TEM-EDS}

As previously shown in Figure 1, the spherical $\mathrm{Al}_{2} \mathrm{Ca}$ intermetallic precipitates were formed in the $\mathrm{Mg}-\mathrm{Al}-\mathrm{CaO}$ precursors with $10-\mathrm{vol} \% \mathrm{CaO}$ particles after the heat treatment at $500{ }^{\circ} \mathrm{C}$ for $3.6 \mathrm{ks}$. On the other hand, a short heat treatment caused the formation of needle-like intermetallics as intermediate precipitates. Our previous study [12] reported that these intermediate compounds were detected as $(\mathrm{Mg}, \mathrm{Al})_{2} \mathrm{Ca}$ or $\mathrm{Al}_{3} \mathrm{Ca}_{4} \mathrm{Mg}$. However, the detailed structure was not completely identified. Therefore, a microstructural analysis of the intermediate precipitates was carried out. Figure 10a shows TEM-EDS line analysis results of an intermediate precipitate in the $\mathrm{Mg}-\mathrm{Al}-\mathrm{CaO}$ precursor with $10-\mathrm{vol} \% \mathrm{CaO}$ particles after the heat treatment at $500{ }^{\circ} \mathrm{C}$ for $300 \mathrm{~s} . \mathrm{Mg}, \mathrm{Al}$, and $\mathrm{Ca}$ were detected. Table 2 shows the chemical composition of this precipitate. The $(\mathrm{Mg}+\mathrm{Al}) / \mathrm{Ca}$ ratio was 2.09. Therefore, the intermediate precipitate was identified as $(\mathrm{Mg}, \mathrm{Al})_{2} \mathrm{Ca}$. Figure $10 \mathrm{~b}$ shows TEM observation and electron diffraction analysis on the precipitate. Rzychon et al. [19] reported that a $(\mathrm{Mg}, \mathrm{Al})_{2} \mathrm{Ca}$ Laves phase with a hexagonal $\mathrm{C} 36$ structure was formed in the Mg-5Al-3Ca- $0.7 \mathrm{Sr}-0.2 \mathrm{Mn}$ alloy. Then, identification of the diffraction pattern in Figure 10(b-2) was determined by referring to the XRD pattern of $(\mathrm{Mg}, \mathrm{Al})_{2} \mathrm{Ca}$ reported in the study [19]. Table 3 shows the referred XRD peak degrees of $(\mathrm{Mg}, \mathrm{Al})_{2} \mathrm{Ca}$ and the lattice spacing calculated by the following Bragg reflection equation:

$$
2 \mathrm{~d} \sin \theta=\mathrm{n} \lambda
$$

where $\lambda$ is the $\mathrm{X}$-ray $(\mathrm{Cu}-\mathrm{K} \alpha)$ wavelength of $1.5418 \AA, \mathrm{n}$ is the diffraction order of 1 , and $\mathrm{d}$ is the lattice spacing. Diffraction spots indicated by the arrows in Figure 10(b-2) correspond to the lattice spacing of $(\mathrm{Mg}, \mathrm{Al})_{2} \mathrm{Ca}$ according to the data of Table 3 . As a result, this compound was identified as a $(\mathrm{Mg}, \mathrm{Al})_{2} \mathrm{Ca}$ phase. 


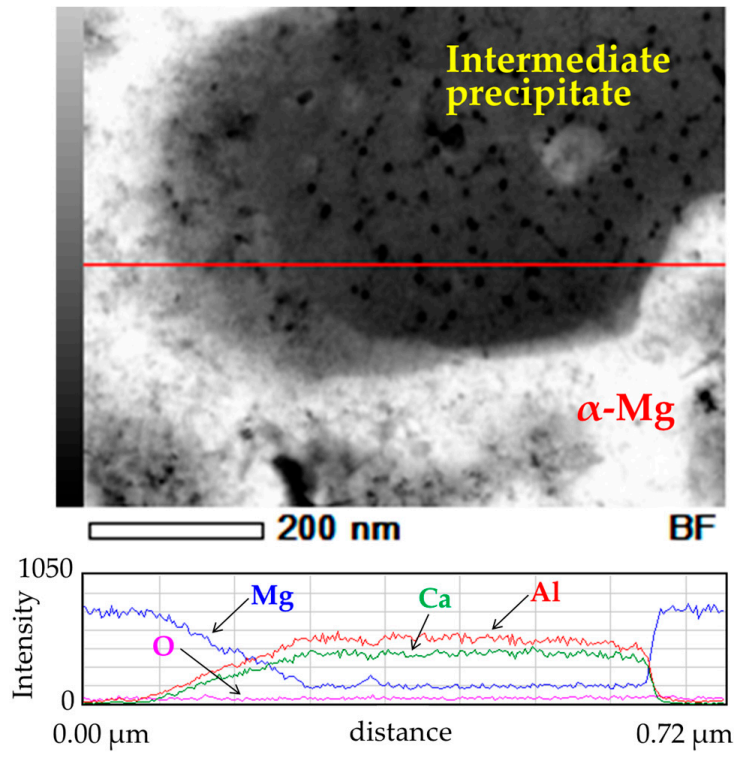

(a) TEM-EDS line analysis.

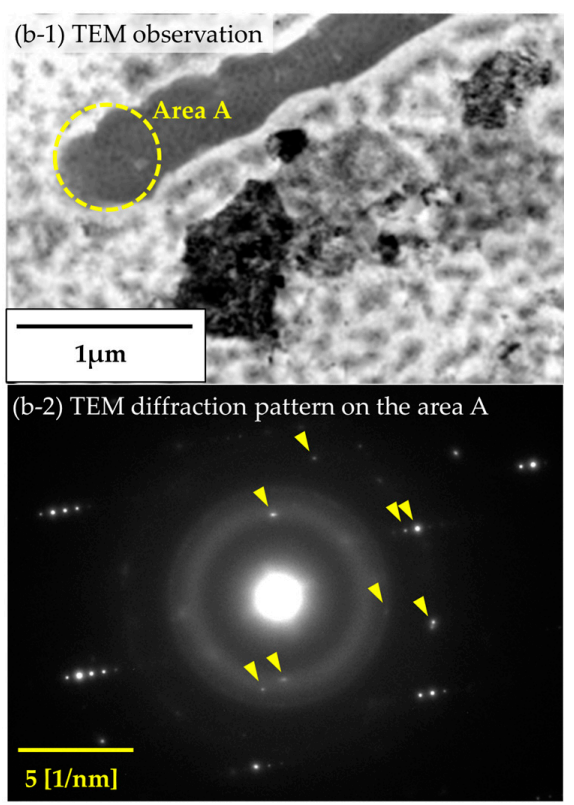

(b) TEM observation and diffraction analysis.

Figure 10. TEM observation on intermediate precipitate in the $\mathrm{Mg}-\mathrm{Al}-\mathrm{CaO}$ precursor with $10-\mathrm{vol} \%$ $\mathrm{CaO}$ particles after the heat treatment at $500{ }^{\circ} \mathrm{C}$ for $300 \mathrm{~s}$.

Table 2. Chemical compositions of intermediate precipitates in the $\mathrm{Mg}-\mathrm{Al}-\mathrm{CaO}$ precursor with $10-\mathrm{vol} \%$ $\mathrm{CaO}$ particles after the heat treatment at $500^{\circ} \mathrm{C}$ for $300 \mathrm{~s}$.

\begin{tabular}{cccccccc}
\hline Element (at \%) & $\mathbf{M g}$ & $\mathbf{A l}$ & $\mathbf{C a}$ & $\mathbf{O}$ & $\mathbf{M n}$ & Zn & Total \\
\hline Intermediate precipitate & 12.34 & 48.84 & 29.29 & 8.98 & 0.16 & 0.40 & 100.00 \\
\hline
\end{tabular}

Table 3. (Mg,Al) $)_{2}$ Ca peak degrees of X-ray diffraction in Rzychoń's work [19] and calculated lattice spacing from these peak degrees.

\begin{tabular}{cc}
\hline XRD Peak Degree, $\mathbf{2 \theta}\left(\mathbf{(}^{\circ}\right)$ & Calculated Lattice Spacing, $\mathbf{d}(\AA)$ \\
\hline 29.44 & 3.033 \\
30.65 & 2.916 \\
33.53 & 2.673 \\
38.20 & 2.356 \\
43.01 & 2.103 \\
49.54 & 1.840 \\
56.80 & 1.621 \\
61.57 & 1.506 \\
\hline
\end{tabular}

\subsection{Identification of the Intermediate Precipitates by XRD}

In the above discussion, a phase identification was carried out by using only the XRD peak degrees

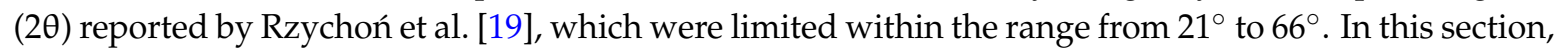
XRD analysis was carried out in order to identify the same intermetallic precipitates by using the lattice spacing calculated from the lattice parameters of the $(\mathrm{Mg}, \mathrm{Al})_{2} \mathrm{Ca}$ phase. Figure 11 shows the XRD profile of the $\mathrm{Mg}-\mathrm{Al}-\mathrm{CaO}$ precursor with 10-vol \% CaO particles after the heat treatment at $500{ }^{\circ} \mathrm{C}$ for $300 \mathrm{~s}$. The diffraction peaks indicated by triangles $(\boldsymbol{\Delta})$ are estimated as the $(\mathrm{Mg}, \mathrm{Al})_{2} \mathrm{Ca}$ compound. The diffraction angles indicated by diamonds $(\diamond$ and $\diamond)$ were calculated from the lattice spacing of $(\mathrm{Mg}, \mathrm{Al})_{2} \mathrm{Ca}$ in the way described below. 


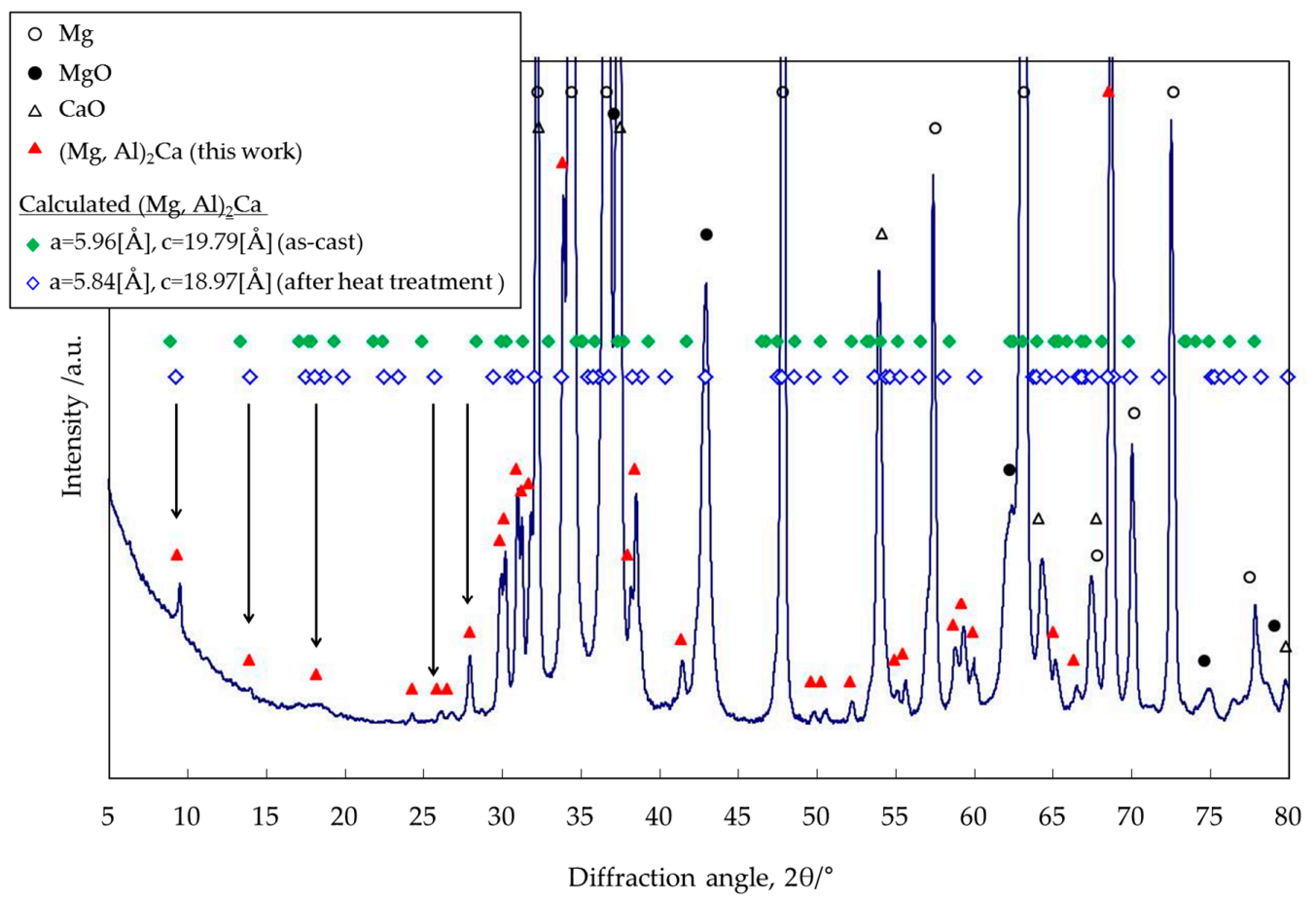

Figure 11. X-ray diffraction pattern of the $\mathrm{Mg}-\mathrm{Al}-\mathrm{CaO}$ precursor with $10-\mathrm{vol} \% \mathrm{CaO}$ particles after the heat treatment at $500{ }^{\circ} \mathrm{C}$ for $300 \mathrm{~s}$.

The lattice spacing (dhkl) of the $(\mathrm{Mg}, \mathrm{Al})_{2}$ Ca phase can be calculated by the following Equation (3) because it has a hexagonal C36 structure:

$$
\frac{1}{d_{h k l}}=\sqrt{\frac{4}{3} \frac{h^{2}+h k+k^{2}}{a^{2}}+\frac{l^{2}}{c^{2}}}
$$

where $h, k$, and $l$ are the Miller indices, and a and c are the lattice parameters, respectively. Recently, many studies have reported that four kinds of Laves phases were formed in the $\mathrm{Mg}-\mathrm{Al}-\mathrm{Ca}$ system: $\mathrm{Al}_{2} \mathrm{Ca}, \mathrm{Mg}_{2} \mathrm{Ca}$, $(\mathrm{Mg}, \mathrm{Al})_{2} \mathrm{Ca}$, and $\mathrm{Al}_{2}(\mathrm{Mg}, \mathrm{Ca})$ [16,19-24]. The lattice parameters of the $(\mathrm{Mg}, \mathrm{Al})_{2} \mathrm{Ca}$ and $\mathrm{Al}_{2}(\mathrm{Mg}, \mathrm{Ca})$ phases have no specific value because of the variable compositions [16,24]. Suzuki et al. [16] reported that the $(\mathrm{Mg}, \mathrm{Al})_{2} \mathrm{Ca}$ Laves phase was crystallized in the $\mathrm{Mg}-\mathrm{Al}-\mathrm{Ca}$ die-cast alloy with a C36 di-hexagonal structure, which was an intermediate between $\mathrm{Mg}_{2} \mathrm{Ca}$ with a $\mathrm{C} 14$ hexagonal structure and $\mathrm{Al}_{2} \mathrm{Ca}$ with a $\mathrm{C} 15$ cubic structure. According to the previous study [16], in the as-cast state, most of the $\mathrm{Al}$ atoms existed in the $\alpha-\mathrm{Mg}$ matrix phase as a $\mathrm{Mg}-\mathrm{Al}$ supersaturated solid-solution. Therefore, the crystal structure and composition of the $(\mathrm{Mg}, \mathrm{Al})_{2} \mathrm{Ca}$ compound were close to the $\mathrm{Mg}_{2} \mathrm{Ca}$ phase. On the other hand, after a heat treatment, both became close to the $\mathrm{Al}_{2} \mathrm{Ca}$ phase because of the $\mathrm{Al}$ diffusion and substitution of $\mathrm{Al}$ for $\mathrm{Mg}$ in the $\alpha-\mathrm{Mg}$ matrix contained in $(\mathrm{Mg}, \mathrm{Al})_{2} \mathrm{Ca}$. Table 4 shows the lattice parameters of the $(\mathrm{Mg}, \mathrm{Al})_{2} \mathrm{Ca}$ compound in the as-cast state and after a heat treatment referred from the previous study [16]. The lattice parameters after the heat treatment became smaller with an increase in the $\mathrm{Al}$ concentration of the $(\mathrm{Mg}, \mathrm{Al})_{2} \mathrm{Ca}$ compound. This is because the atomic radius of $\mathrm{Al}(1.43 \AA)$ is smaller than that of $\mathrm{Mg}(1.60 \AA)$, as mentioned above.

Table 4. Crystal structures and lattice parameters of $(\mathrm{Mg}, \mathrm{Al})_{2} \mathrm{Ca}$ Laves phases [16].

\begin{tabular}{|c|c|c|c|c|}
\hline \multirow{2}{*}{ Compound } & \multirow{2}{*}{ Type } & \multirow{2}{*}{ Structure } & \multicolumn{2}{|c|}{ Lattice Parameter } \\
\hline & & & a ( $(\AA)$ & c ( $(̊)$ \\
\hline \multirow{2}{*}{$(\mathrm{Mg}, \mathrm{Al})_{2} \mathrm{Ca}$} & \multirow{2}{*}{$\mathrm{C} 36$} & di-hexagonal (as-cast) & 5.96 & 19.79 \\
\hline & & di-hexagonal (after heat treatment) & 5.84 & 18.97 \\
\hline
\end{tabular}


Based on the above consideration, the lattice spacing of $(\mathrm{Mg}, \mathrm{Al})_{2} \mathrm{Ca}$ was calculated from the two kinds of lattice parameters indicated in Table 4 by using Equation (3). After that, the XRD peak degrees were converted from the lattice spacing by Equation (2). Table 5 shows the calculated results. The Miller indices $(h, k$ and $l)$ were $0,1,2,3,4$, and 5 . The calculated values $(2 \theta)$ are shown within the range from $0^{\circ}$ to $80^{\circ}$. The XRD peak degrees calculated from both lattice parameters in Table 4 were similar. These values after the heat treatment were a little larger than those in the as-cast state due to the smaller lattice parameter. The calculated diffraction angles in the as-cast state and after the heat treatment are indicated by two kinds of diamonds $(\checkmark$ and $\diamond)$, respectively, shown in Figure 11. Not all calculated peaks of the $(\mathrm{Mg}, \mathrm{Al})_{2} \mathrm{Ca}$ Laves phase were detected because the calculated results in Table 5 included no information about their intensities. The diffraction peaks estimated as $(\mathrm{Mg}, \mathrm{Al})_{2} \mathrm{Ca}(\boldsymbol{\Lambda})$ roughly correspond to those of the calculated ones ( $\diamond$ and $\diamond)$. The low-angled peaks indicated by arrows matched them especially well. As a result, the intermediate compound was identified as the $(\mathrm{Mg}, \mathrm{Al})_{2} \mathrm{Ca}$ Laves phase. In addition, the detected peaks at $\sim 9.5^{\circ}$ and $\sim 14^{\circ}$ correspond to the calculated ones for after the heat treatment rather than those of the as-cast state. According to the above analysis and discussion, this suggests that the crystal structure and compositions of the intermediate compound are closer to $\mathrm{Al}_{2} \mathrm{Ca}$ than they are to $\mathrm{Mg}_{2} \mathrm{Ca}$. This also agrees with the result showing that the $\mathrm{Al}$ content of the compound was much higher than the $\mathrm{Mg}$ content as shown in Table 2. It is expected that the crystal structure of the intermediate precipitate becomes much closer to that of $\mathrm{Al}_{2} \mathrm{Ca}$ when a long heat treatment is employed. This is because $\mathrm{Al}$ atoms in the $\alpha-\mathrm{Mg}$ matrix are substituted for $\mathrm{Mg}$ atoms contained in $(\mathrm{Mg}, \mathrm{Al})_{2} \mathrm{Ca}$. As a result, $\mathrm{Al}_{2} \mathrm{Ca}$ compounds were homogeneously dispersed after the heat treatment for $3.6 \mathrm{ks}$ as shown in Figure 1. Their shapes became spherical in order to reduce the surface energy.

Table 5. Miller indices and calculated diffraction angles of $(\mathrm{Mg}, \mathrm{Al})_{2} \mathrm{Ca}$ Laves phase.

\begin{tabular}{|c|c|c|c|c|c|c|c|c|c|c|c|}
\hline \multicolumn{4}{|c|}{ Miller Indice } & \multicolumn{2}{|c|}{ Diffraction Angle, $2 \theta\left(^{\circ}\right)$} & \multicolumn{4}{|c|}{ Miller Indice } & \multicolumn{2}{|c|}{ Diffraction Angle, $2 \theta\left(^{\circ}\right)$} \\
\hline$h$ & $k$ & $i$ & $l$ & $\begin{array}{c}\text { As-Cast } \\
(\mathrm{a}=5.96(\AA)) \\
(\mathrm{c}=19.79(\AA))\end{array}$ & $\begin{array}{c}\text { After Heat Treatment } \\
(\mathrm{a}=5.84(\AA))) \\
(\mathrm{c}=18.97(\AA))\end{array}$ & $h$ & $k$ & $i$ & $l$ & $\begin{array}{c}\text { As-Cast } \\
(\mathrm{a}=5.96(\AA)) \\
(\mathrm{c}=19.79(\AA))\end{array}$ & $\begin{array}{c}\text { After Heat Treatment } \\
(\mathrm{a}=5.84(\AA)) \\
(\mathrm{c}=18.97(\AA))\end{array}$ \\
\hline 0 & 0 & 0 & 1 & 4.46 & 4.66 & 2 & 1 & -3 & 4 & 50.27 & 51.55 \\
\hline 0 & 0 & 0 & 2 & 8.94 & 9.32 & 2 & 1 & -3 & 5 & 52.28 & 53.69 \\
\hline 0 & 0 & 0 & 3 & 13.42 & 14.01 & 3 & 0 & -3 & 0 & 53.24 & 54.42 \\
\hline 1 & 0 & -1 & 0 & 17.18 & 17.53 & 3 & 0 & -3 & 1 & 53.46 & 54.65 \\
\hline 1 & 0 & -1 & 1 & 17.76 & 18.15 & 3 & 0 & -3 & 2 & 54.10 & 55.35 \\
\hline 0 & 0 & 0 & 4 & 17.93 & 18.71 & 3 & 0 & -3 & 3 & 55.17 & 56.49 \\
\hline 1 & 0 & -1 & 2 & 19.40 & 19.89 & 3 & 0 & -3 & 4 & 56.64 & 58.07 \\
\hline 1 & 0 & -1 & 3 & 21.86 & 22.51 & 3 & 0 & -3 & 5 & 58.49 & 60.05 \\
\hline 0 & 0 & 0 & 5 & 22.46 & 23.45 & 2 & 2 & -4 & 0 & 62.31 & 63.74 \\
\hline 1 & 0 & -1 & 4 & 24.93 & 25.75 & 2 & 2 & -4 & 1 & 62.51 & 63.95 \\
\hline 1 & 0 & -1 & 5 & 28.42 & 29.43 & 2 & 2 & -4 & 2 & 63.10 & 64.58 \\
\hline 1 & 1 & -2 & 0 & 29.98 & 30.62 & 2 & 2 & -4 & 3 & 64.07 & 65.63 \\
\hline 1 & 1 & -2 & 1 & 30.33 & 30.99 & 3 & 1 & -4 & 0 & 65.16 & 66.68 \\
\hline 1 & 1 & -2 & 2 & 31.35 & 32.07 & 3 & 1 & -4 & 1 & 65.36 & 66.88 \\
\hline 1 & 1 & -2 & 3 & 32.98 & 33.81 & 2 & 2 & -4 & 4 & 65.41 & 67.07 \\
\hline 2 & 0 & -2 & 0 & 34.76 & 35.50 & 3 & 1 & -4 & 2 & 65.93 & 67.50 \\
\hline 2 & 0 & -2 & 1 & 35.06 & 35.82 & 3 & 1 & -4 & 3 & 66.88 & 68.52 \\
\hline 1 & 1 & -2 & 4 & 35.15 & 36.12 & 2 & 2 & -4 & 5 & 67.12 & 68.91 \\
\hline 2 & 0 & -2 & 2 & 35.96 & 36.78 & 3 & 1 & -4 & 4 & 68.19 & 69.93 \\
\hline 2 & 0 & -2 & 3 & 37.42 & 38.33 & 3 & 1 & -4 & 5 & 69.87 & 71.74 \\
\hline 1 & 1 & -2 & 5 & 37.79 & 38.92 & 4 & 0 & -4 & 0 & 73.37 & 75.14 \\
\hline 2 & 0 & -2 & 4 & 39.38 & 40.42 & 4 & 0 & -4 & 1 & 73.55 & 75.33 \\
\hline 2 & 0 & -2 & 5 & 41.78 & 42.98 & 4 & 0 & -4 & 2 & 74.10 & 75.92 \\
\hline 2 & 1 & -3 & 0 & 46.55 & 47.57 & 4 & 0 & -4 & 3 & 75.00 & 76.89 \\
\hline 2 & 1 & -3 & 1 & 46.79 & 47.82 & 4 & 0 & -4 & 4 & 76.25 & 78.25 \\
\hline 2 & 1 & -3 & 2 & 47.50 & 48.58 & 4 & 0 & -4 & 5 & 77.86 & 79.98 \\
\hline 2 & 1 & -3 & 3 & 48.67 & 49.83 & - & - & - & - & - & - \\
\hline
\end{tabular}




\section{Conclusions}

AZ61B composite powder precursors with 10-vol \% CaO additive particles prepared via the ECABMA process were heat treated to synthesize $\mathrm{Al}_{2} \mathrm{Ca}$ intermetallic precipitates in a solid-state reaction. SEM-EDS and EPMA were applied to investigate the distribution of $\mathrm{Al}$ atoms in the AZ61B powder precursor. The precursor before the heat treatment indicated that the $\alpha-\mathrm{Mg}$ matrix contained $4.7-a t \%$ $\mathrm{Al}$ atoms and the remaining $\mathrm{Al}$ elements contributed to forming $\mathrm{Mg}_{17} \mathrm{Al}_{12}$ or $\mathrm{Al}_{6} \mathrm{Mn}$ compounds in the matrix. TEM-EDS and XRD analysis on the AZ61B composite precursor in the initial reaction stage showed that $\mathrm{CaO}$ additives were thermally decomposed in the $\mathrm{Mg}-\mathrm{Al}$ alloy matrix, and solid-soluted Ca atoms diffused along the $\alpha-\mathrm{Mg}$ grain boundaries. Al atoms also diffused to the grain boundaries because of their strong affinity for $\mathrm{Ca}$ atoms. As a result, needle-like $(\mathrm{Mg}, \mathrm{Al})_{2} \mathrm{Ca}$ intermetallics were formed as intermediate precipitates at the initial stage of the heat treatment. They were completely transformed into the spherical $\mathrm{Al}_{2} \mathrm{Ca}$ phases by substitution of $\mathrm{Al}$ atoms for $\mathrm{Mg}$ atoms of the above $(\mathrm{Mg}, \mathrm{Al})_{2} \mathrm{Ca}$ intermediates after a long heat treatment.

Acknowledgments: The authors would like to thank Keitaro Enami, Masaki Ohara, Takanori Igarashi from TOPY Industries, Limited, for supporting preparation of AZ61B precursors containing CaO particles via ECABMA process.

Author Contributions: Junji Fujita and Katsuyoshi Kondoh conceived and designed the experiments. Junji Fujita performed the experiments. Junji Fujita and Junko Umeda analyzed the results. Junji Fujita wrote the pater. Junko Umeda and Katsuyoshi Kondoh supervised the experiments and the paper.

Conflicts of Interest: The authors declare no conflict of interest.

\section{References}

1. Gupta, M.; Sharon, N.M.L. Magnesium, Magnesium Alloys, and Magnesium Composites; John Wiley \& Sons: Hoboken, NJ, USA, 2011.

2. U.S. Geological Survey. Mineral Commodity Summaries; U.S. Geological Survey: Reston, VA, USA, 2015.

3. Tharumarajah, A.; Koltun, P. Is there an environmental advantage of using magnesium components for light-weighting cars? J. Clean. Prod. 2007, 15, 1007-1013. [CrossRef]

4. Luo, A.A. Magnesium casting technology for structural applications. J. Magnes. Alloys 2013, 1, 2-22. [CrossRef]

5. Bettles, C.J.; Gibson, M.A.; Zhu, S.M. Microstructure and mechanical behaviour of an elevated temperature Mg-rare earth based alloy. Mater. Sci. Eng. A 2009, 505, 6-12. [CrossRef]

6. Pekguleryuz, M.O.; Kaya, A.A. Creep resistant magnesium alloys for powertrain applications. Adv. Eng. Mater. 2003, 5, 866-878. [CrossRef]

7. Anyanwu, I.A.; Gokan, Y.; Suzuki, A.; Kamado, S.; Kojima, Y.; Takeda, S.; Ishida, T. Effect of substituting cerium-rich mischmetal with lanthanum on high temperature properties of die-cast $\mathrm{Mg}-\mathrm{Zn}-\mathrm{Al}-\mathrm{Ca}-\mathrm{RE}$ alloys. Mater. Sci. Eng. A 2004, 380, 93-99. [CrossRef]

8. Amberger, D.; Eisenlohr, P.; Göken, M. Microstructural evolution during creep of Ca-containing AZ91. Mater. Sci. Eng. A 2009, 510, 398-402. [CrossRef]

9. Kondori, B.; Mahmudi, R. Effect of Ca additions on the microstructure, thermal stability and mechanical properties of a cast AM60 magnesium alloy. Mater. Sci. Eng. A 2010, 527, 2014-2021. [CrossRef]

10. Xu, S.W.; Matsumoto, N.; Yamamoto, K.; Kamado, S.; Honma, T.; Kojima, Y. High temperature tensile properties of as-cast Mg-Al-Ca alloys. Mater. Sci. Eng. A 2009, 509, 105-110. [CrossRef]

11. Ellingham, H.J.T. The physical chemistry of process metallurgy. J. Soc. Chem. Ind. 1944, 63, 125-133.

12. Kondoh, K.; Fujita, J.; Umeda, J.; Imai, H.; Enami, K.; Ohara, M.; Igarashi, T. Thermo-dynamic analysis on solid-state reduction of $\mathrm{CaO}$ particles dispersed in $\mathrm{Mg}-\mathrm{Al}$ alloy. Mater. Chem. Phys. 2011, 129, 631-640. [CrossRef]

13. Enami, K.; Ohara, M.; Igarashi, T.; Fujita, J.; Kondoh, K. Development of Heat-Resistant Magnesium Composites by Bulk Mechanical Alloying Method. J. Jpn. Soc. Powder Powder Metall. 2009, 56, 717-721. (In Japanese) [CrossRef] 
14. Enami, K.; Fujita, Y.; Motoe, Y.; Ohara, M.; Igarashi, T.; Kondoh, K. Development of magnesium alloy composites by bulk mechanical alloying process. J. Jpn. Soc. Powder Metall. 2008, 55, 244-249. (In Japanese) [CrossRef]

15. Massalski, T.B. Binary Alloy Phase Diagrams; American Society for Metals: Metals Park, OH, USA, 1986; Volume 1.

16. Suzuki, A.; Saddock, N.D.; Jones, J.W.; Pollock, T.M. Structure and transition of eutectic $(\mathrm{Mg}, \mathrm{Al})_{2} \mathrm{Ca}$ Laves phase in a die-cast Mg-Al-Ca base alloy. Scr. Mater. 2004, 51, 1005-1010. [CrossRef]

17. Petzow, G.; Effenberg, G. Ternary Alloys, A Comprehensive Compendium of Evaluated Constitutional Data and Phase Diagrams; Verlagsgesellschaft: Weinheim, Germany, 1990; Volume 3, p. 614.

18. Nakaura, Y.; Watanabe, A.; Ohori, K. Effects of Ca, Sr Additions on Properties of Mg-Al Based Alloys. Mater. Trans. 2006, 47, 1031-1039. [CrossRef]

19. Rzychon, T.; Chmiela, B. The influence of tin on the microstructure and creep properties of a Mg-5Al-3Ca0.7Sr-0.2Mn magnesium alloy. Solid State Phenom. 2012, 191, 151-158. [CrossRef]

20. Suzuki, A.; Saddock, N.D.; Jones, J.W.; Pollock, T.M. Solidification paths and eutectic intermetallic phases in Mg-Al-Ca ternary alloys. Acta Mater. 2005, 53, 2823-2834. [CrossRef]

21. Zhong, Y.; Liu, J.; Witt, R.A.; Sohn, Y.; Liu, Z. $\mathrm{Al}_{2}(\mathrm{Mg}, \mathrm{Ca})$ phases in Mg-Al-Ca ternary system: First-principles prediction and experimental identification. Scr. Mater. 2006, 55, 573-576. [CrossRef]

22. Suzuki, A.; Saddock, N.D.; Jones, J.W.; Pollock, T.M. Phase Equilibria in the Mg-Al-Ca Ternary System at 773 and 673 K. Metall. Mater. Trans. A 2006, 37, 975-976. [CrossRef]

23. Janz, A.; Grobner, J.; Cao, H.; Zhu, J.; Chang, Y.A.; Schmid-Fetzer, R. Thermodynamic modeling of the Mg-Al-Ca system. Acta Mater. 2009, 57, 682-694. [CrossRef]

24. Kevorkov, D.; Medraj, M.; Li, J.; Essadiqi, E.; Chartrand, P. The $400{ }^{\circ} \mathrm{C}$ isothermal section of the $\mathrm{Mg}-\mathrm{Al}-\mathrm{Ca}$ system. Intermetallics 2010, 18, 1498-1506. [CrossRef]

(C) 2017 by the authors. Licensee MDPI, Basel, Switzerland. This article is an open access article distributed under the terms and conditions of the Creative Commons Attribution (CC BY) license (http:// creativecommons.org/licenses/by/4.0/). 